University of Nebraska - Lincoln

DigitalCommons@University of Nebraska - Lincoln

Faculty Publications: Department of Entomology

10-1-1999

\title{
Blissus occiduus (Hemiptera: Lygaeidae): A Chinch Bug Pest New to Buffalograss Turf
}

Frederick P. Baxendale

University of Nebraska-Lincoln, fbaxendale1@unl.edu

Tiffany Heng-Moss

University of Nebraska-Lincoln, thengmoss2@unl.edu

Terrance P. Riordan

University of Nebraska-Lincoln, triordan1@unl.edu

Follow this and additional works at: https://digitalcommons.unl.edu/entomologyfacpub

Part of the Entomology Commons

Baxendale, Frederick P.; Heng-Moss, Tiffany; and Riordan, Terrance P., "Blissus occiduus (Hemiptera: Lygaeidae): A Chinch Bug Pest New to Buffalograss Turf" (1999). Faculty Publications: Department of Entomology. 138.

https://digitalcommons.unl.edu/entomologyfacpub/138

This Article is brought to you for free and open access by the Entomology, Department of at DigitalCommons@University of Nebraska - Lincoln. It has been accepted for inclusion in Faculty Publications: Department of Entomology by an authorized administrator of DigitalCommons@University of Nebraska - Lincoln. 


\title{
Blissus occiduus (Hemiptera: Lygaeidae): A Chinch Bug Pest New to Buffalograss Turf
}

\author{
FREDERICK P. BAXENDALE, TIFFANY M. HENG-MOSS, AND TERRANCE P. RIORDAN ${ }^{1}$
}

Entomology Department, University of Nebraska, 202 Plant Industry, Lincoln, NE 68583-0816

\begin{abstract}
J. Econ. Entomol. 92(5): 1172-1176 (1999)
ABSTRACT Blissus occiduus Barber, a relatively small chinch bug characterized by conspicuous wing dimorphism, has emerged as an important insect pest of buffalograss, Buchloe dactyloides (Nuttall) Engelmann. It completes 2 generations a year on buffalograss in Nebraska. Overwintered adults become active as early as mid-March. Depending on the season, 1st-generation nymphs can be present from early May through early August, with 1st-generation adults (up to $60 \%$ macropterous forms) appearing in mid to late June. Second generation nymphs can be present from early July through fall, with 2nd-generation adults appearing in late August to early September. These predominately brachypterous ( $>95 \%$ ) adults overwinter in and around the turf area. Blissus occiduus was confirmed to be associated with natural buffalograss pastures, seeded and vegetatively propagated buffalograss lawns, right-of-ways, cemeteries, and golf courses in 21 Nebraska counties. Chinch bugs were generally found feeding on the stolons and in the crown area of the buffalograss plant. Initial $B$. occiduus injury resulted in reddish discoloration of infested plant tissues. As feeding progressed, damage appeared as patchy areas in the turf that turned from yellow to straw-brown. At higher infestation levels, chinch bug feeding resulted in severe thinning or death of the buffalograss stand. Field studies documented buffalograss as a reproductive host of $B$. occiduus, with Kentucky bluegrass and perennial ryegrass identified as potential hosts. Creeping bentgrass, tall fescue, and zoysiagrass did not appear to be suitable turfgrass hosts for B. occiduts.
\end{abstract}

KEY WORDS Blissus occiduus, Buchloë dactyloides, turf

Buffalograss, Buchloë dactyloides (Nuttall) Engelmann, is a perennial, warm-season grass native to the semiarid regions of the North American Great Plains (Wenger 1943). In recent years, it has gained popularity as an alternative turfgrass species because of its lower maintenance.requirements and relative freedom from diseases and arthropod pests. As a turfgrass, established buffalograss requires less mowing, irrigation, fertilizer, and fewer pesticide applications than traditional turfgrass species (Pozarnsky 1983, Riordan et al. 1993).

Few arthropods are considered serious pests of buffalograss. Baxendale et al. (1994) reviewed the arthropods reported to be injurious to buffalograss, and discussed the biology, distribution and significance of Tridiscus sporoboli (Cockerell) and Trionymus sp. (Homoptera: Pseudococcidae), 2 mealybug pests previously unreported from buffalograss. Reference also was made to an unknown species of chinch bug that was severely damaging buffalograss turf in Lincoln, $\mathrm{NE}$. This chinch bug was subsequently identified as Blissus occiduus Barber by Thomas J. Henry, Systematic Entomology Laboratory, ARS-USDA, National Museum of Natural History, Washington, DC.

Chinch bugs, Blissus spp. (Hemiptera: Lygaeidae) are common pests of grain crops, forage grasses and

\footnotetext{
${ }^{1}$ Horticulture Department, 377 Plant Science, University of $\mathrm{Ne}$ braska, Lincoln, NE 68583-0724.
}

turfgrasses throughout much of the United States (Horton and Satterthwait 1922, Leonard 1966, Webster 1909). The important turfgrass-inhabiting species include the common chinch bug, Blissus leucopterus leucopterus (Say); the hairy chinch bug, Blissus leucopterus hirtus Montandon; and the southern chinch bug, Blissus insularis Barber (Reinert et al. 1995). These chinch bugs have been reported as pests of numerous turfgrass species, including Bermuda grass, Cynodon dactylon (L.) Persoon; creeping bentgrass, Agrostis palustris Hudson; Kentucky bluegrass, Poa pratensis L.; perennial ryegrass, Lolium perenne L.; St. Augustinegrass, Stenotaphrum secundatum (Walter) Kuntze; zoysiagrass, Zoysia japonica Steudel.; and the tall and fine fescues, Festuca spp. (Tashiro 1987).

Blissus occiduus was described by Barber in 1918 from specimens collected in Ft. Collins, $\mathrm{CO}$, and Geronimo, NM (Barber 1918). Although B. occiduus was described $>80 \mathrm{yr}$ ago, little is known about its biology and ecology. The reported distribution of $B$. occiduus includes California, Colorado, Montana, and New Mexico in the United States, and Alberta, British Columbia, Manitoba, and Saskatchewan in Canada (Bird and Mitchener 1950, Slater 1964). Among its reported hosts are barley, Hórdeum L.; sugarcane, Saccharum officinárum L; wheat, Triticum aestivum L.; bromegrass, Bromus spp., and "native grasses" (Ferris 1920, Parker 1920, Bird and Mitchener 1950, Farstad and Staff 1951). Until recently, no turfgrass species 
were known to be hosts to B. occiduus. The purpose of this research was to investigate the biology, distribution, and injury potential of $B$. occiduus on buffalograss in Nebraska.

\section{Materials and Methods}

Description, Biology, and Seasonal Occurrence. Information on the biology and seasonal occurrence of B. occiduus was obtained by collecting sod plug samples from chinch bug-infested buffalograss on the University of Nebraska East Campus, Lincoln, NE. A minimum of 12 samples was taken every week (May-September) or 2 wk (March-April and October-November) during 1991 and 1992 using a golf cup cutter $(10.6 \mathrm{~cm}$ diameter). Sod plugs were taken to the laboratory and placed in Berlese funnels (Southwood 1978) fitted with 40 -watt incandescent lights and maintained at $\approx 38^{\circ} \mathrm{C}$ for $72 \mathrm{~h}$ to extract $B$. occiduus. Chinch bugs extracted from plugs were collected in $70 \%$ ethyl alcohol for later identification, characterization (e.g., age class, sex, wing dimorphism), and counting. $B$. occiduus nymphs were divided into 5 instars based on body dimensions and color (Slater 1979). The body length of 100 individuals in all $B$. occiduus age classes were measured at $20 \times$ using a stereo microscope fitted with a calibrated optical grid. Mean lengths and their standard errors were calculated for all age classes. Color and distinguishing markings also were recorded.

Distribution and Damage. A survey of B. occiduus distribution in Nebraska was conducted by collecting and examining sod plug samples from buffalograss stands in the southern, central, and southeastern portions of the state during 1990-1992. Samples were taken from natural buffalograss stands in pastures, and from seeded and vegetatively propagated buffalograss in lawns, right-of-ways, cemeteries, and golf courses. Field observations on $B$. occiduus feeding location and injury to buffalograss also were recorded. Chinch bugs were extracted from sod plug samples using Berlese funnels as described above. Records of B. occiduus in buffalograss samples submitted to the University of Nebraska Plant and Pest Diagnostic Clinic served to identify additional locations.

Turfgrass Hosts. To identify potential turfgrass hosts, B. occiduus were caged on field plots of Kentucky bluegrass, bentgrass, tall fescue, zoysiagrass, perennial ryegrass, and ' 609 ' buffalograss. Four openended ( $15.5 \mathrm{~cm}$ diameter, $17 \mathrm{~cm}$ high) metal cylinders were implanted $2.5 \mathrm{~cm}$ into the soil of each turfgrass species. Chinch bugs were collected from a 'Texoka' buffalograss lawn at the University of Nebraska East Campus, Lincoln. Ten adult chinch bugs ( 5 males and 5 females) were introduced into each cage and the tops were covered with organdy fabric to prevent chinch bug escape. After $60 \mathrm{~d}$ (17 July-15 September), the sod core enclosed by each cage was excised to a depth of $5 \mathrm{~cm}$ and placed in a Berlese funnel to extract established chinch bugs. Turfgrass quality (1-9 scale, where 9 is best density, color, and overall appearance [Skogley and Sawyer 1992]) within enclosures was evaluated at harvest.

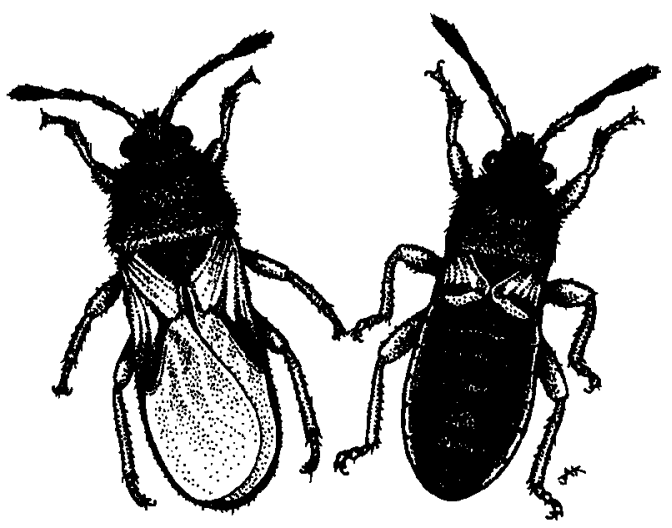

Fig. 1. Comparison of macropterous (left) and brachypterous (right) adults of $B$. occiduus.

\section{Results and Discussion}

Description, Biology, and Seasonal Occurrence. Blissus occiduus exhibits conspicuous wing dimorphism (Fig. 1). Brachypterous females (3.10 \pm 0.02 $\mathrm{mm})$ (mean $\pm \mathrm{SE}$ ) and males $(2.72 \pm 0.02 \mathrm{~mm})$ are significantly larger than macropterous females $(2.78 \pm$ $0.06 \mathrm{~mm}$ ) and males $(2.53 \pm 0.01 \mathrm{~mm}$ ) (female: $F=$ 28.33; $\mathrm{df}=1,199 ; P<0.0001$; male: $F=14.00 ; \mathrm{df}=1$, $199 ; P<0.0002)$. B. occiduus eggs are oval, pale yellow, and $0.86 \pm 0.006 \mathrm{~mm}$ in length. They are deposited in buffalograss crowns, within the leaf sheaths, or in the organic debris and soil. Bright red with a white band across the abdomen, 1 st and 2 nd instars average $1.03 \pm$ 0.01 and $1.33 \pm 0.01 \mathrm{~mm}$ in length, respectively; 3rd, 4th, and 5 th instars progressively darken from orangebrown to black and average $1.89 \pm 0.02,1.97 \pm 0.02$, and $2.41 \pm 0.06 \mathrm{~mm}$ in length, respectively.

Blissus occiduus completes 2 generations a year on buffalograss in Nebraska (Table 1). In 1991, overwintered $B$. occiduus adults ( $46.2 \%$ males, $53.8 \%$ females) were present in samples from 11 March until 20 May. First instars appeared 6 May with the remaining instars

Table 1. Seasonal occurrence of $\boldsymbol{B}$. occiduus as indicated by number and age class of individuals collected from buffalograss turf at the University of Nebraska East Campus, Lincoln, NE, 1991 and 1992

\begin{tabular}{lcc}
\hline \multicolumn{1}{c}{ Age class } & \multicolumn{1}{c}{ 1991 dates (no.) } & 1992 dates (no.) ${ }^{a}$ \\
\hline $\begin{array}{l}\text { Adults } \\
\text { 1st generation }\end{array}$ & 11 March-20 May (221) & 17 March-11 June (325) \\
1st instar & 6 May-17 June (481) & 21 May-9 July (1,943) \\
2nd instar & 20 May-1 July (117) & 28 May-16 July (621) \\
3rd instar & 28 May-8 July (88) & 4 June-23 July (429) \\
4th instar & 10 June-15 July (53) & 11 June-30 July (375) \\
5th instar & 17 June-15 July (97) & 18 June-6 Aug (494) \\
Adults & 17 June-5 Aug (879) & 25 June-21 Aug (848) \\
2nd generation & & \\
1st instar & 1 July-9 Sept (1,310) & 23 July-17 Sept (644) \\
2nd instar & 15 July-9 Sept (434) & 30 July-15 Oct (370) \\
3rd instar & 24 July-23 Sept (150) & 6 Aug-15 Oct (238) \\
4th instar & 12 Aug-20 Nov (109) & 21 Aug-15 Nov (133) \\
5th instar & 26 Aug-20 Nov (116) & 3 Sept-15 Nov (62) \\
Adults & 26 Aug-20 Nov (741) & 10 Sept-15 Nov (271) \\
\hline
\end{tabular}

${ }^{a}$ Number of individuals collected during indicated time period. 

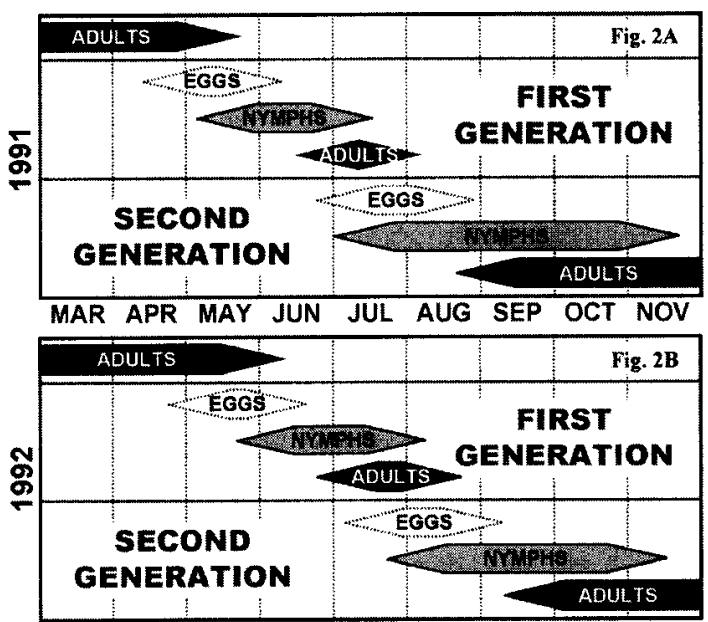

MAR APR MAY JUN JUL AUG SEP OCT NOV

Fig. 2. Diagrammatic representation of seasonal occurrence of $B$. occiduus in Nebraska.

present until 15 July. First-generation adults (45.1\% males, $54.9 \%$ females) were present from 17 June until 5 August. First instars of the 2nd generation began to appear in early July ( 1 July). Second-generation adults (50.1\% males, $49.9 \%$ females) appeared in late August (26 August) and remained active until 20 November when sampling was terminated with the onset of freezing temperatures (Fig. 2A). A similar pattern of seasonal activity was noted by Parker (1920) for this chinch bug on prairie grass in Montana.

The seasonal occurrence pattern of $B$. occiduus was similar in 1992. However, temperatures cooler than normal from May through early July seemed to delay B. occiduus development. Overwintered adults $(49.2 \%$ males, $50.8 \%$ females) were again present in samples taken in mid-March (17 March). However, 1st instars did not appear until 21 May. First-generation adults ( $54.7 \%$ males, $45.3 \%$ females) were collected on 25 June, but 2nd-generation nymphs did not appear until 23 July, which was 3 wk later than in 1991. Firstgeneration adults were present until 21 August. Second-generation adults ( $54.7 \%$ males, $45.3 \%$ females) were collected in early September (10 September) and remained active in the buffalograss until sampling was stopped in November (15 November) (Fig. 2B).

Blissus occiduus overwinters primarily as brachypterous adults. Second-generation (overwintering) chinch bugs collected in mid-November in 1991 and 1992 were 100 and $99.6 \%$ brachypterous, respectively. Macropterous adults, however, can be quite common in the 1st generation. In $1992,63.9 \%$ of lst-generation adults were macropterous, whereas only $6.6 \%$ were macropterous in 1991. The reason for this dramatic year-to-year variability is unclear, but considerable variation often can be observed with respect to wing dimorphism among insect species, including chinch bugs (Dingle 1979). Reasons for this variation have been attributed primarily to environmental suitability, host plant quality, and colonization of new habitats.
Macropterous individuals are generally selected when conditions are unfavorable for continued development, whereas brachypterous individuals are produced when conditions are favorable for development. $B$. occiduus may overwinter as brachypterous adults to ensure they remain near a suitable perennial host plant for growth next spring. Further, macropterous adults may be produced during the summer months to allow for colonization of new turfgrass areas. Mailloux and Streu (1981) reported similar seasonal changes in the relative proportions of macropterous and brachypterous forms of $B$. leucopterus hirtus. Additional research is needed to understand fully the factors affecting wing dimorphism in B. occiduus.

Distribution and Damage. Fig. 3 shows the known distribution of B. occiduus in Nebraska. Survey results revealed the presence of $B$. occiduus in 15 of the 19 counties sampled, and records from the University of Nebraska Plant and Pest Diagnostic Clinic detected $B$. occiduus in 6 additional Nebraska counties (Cass, Dawes, Morrill, Keith, Scotts Bluff, and Thayer). B. occiduus had not previously been recorded from $\mathrm{Ne}-$ braska. B. occiduus was collected from all types of buffalograss stands sampled. Although most samples contained relatively few chinch bugs $\left(<25 / 1.0 \mathrm{~m}^{2}\right), B$. occiduus numbers exceeded 5,000 per $1.0 \mathrm{~m}^{2}$ at several sites. These results and the previously reported distribution of $B$. occiduus indicate a wide geographic range for this chinch bug and suggest the need for further sampling at other locations in the United States where buffalograss is grown as a turfgrass. Because buffalograss stands are primarily established vegetatively with plugs or sod, it is possible that chinch bugs present in the vegetative material may have been inadvertently distributed to other areas where buffalograss is becoming popular as a turfgrass.

Serious chinch bug injury was present in several of the buffalograss stands sampled. B. occiduus was observed feeding on the stolons and in the crown area of the plant. Initially, this resulted in reddish discoloration of affected plant tissues. As feeding progressed, patchy areas, which turned from yellow to strawbrown, appeared in the turf. At higher infestation levels, chinch bug feeding resulted in severe thinning or even death of the buffalograss stand. Chinch bug injury to buffalograss was most prevalent during late July to early September. Interestingly, in some cases there appeared to be little correlation between the number of chinch bugs present and the severity of associated plant damage. One explanation for this observation could be that certain buffalograss genotypes exhibit chinch bug resistance. Preliminary studies (T.M.H., unpublished data) have shown statistically significant differences among buffalograss selections in their ability to tolerate $B$. occiduus feeding.

Turfgrass Hosts. At harvest, all caged turfgrass species showed acceptable (5 or 6 on 1-9 scale) turf quality with little or no visible stress (i.e., high temperature, reduced moisture, low light) symptoms associated with caging or from chinch bug feeding on infested plants. In total, 53 (19 brachypterous males; 14 brachypterous females; and one $3 \mathrm{rd}$, six $4 \mathrm{th}$, and 13 


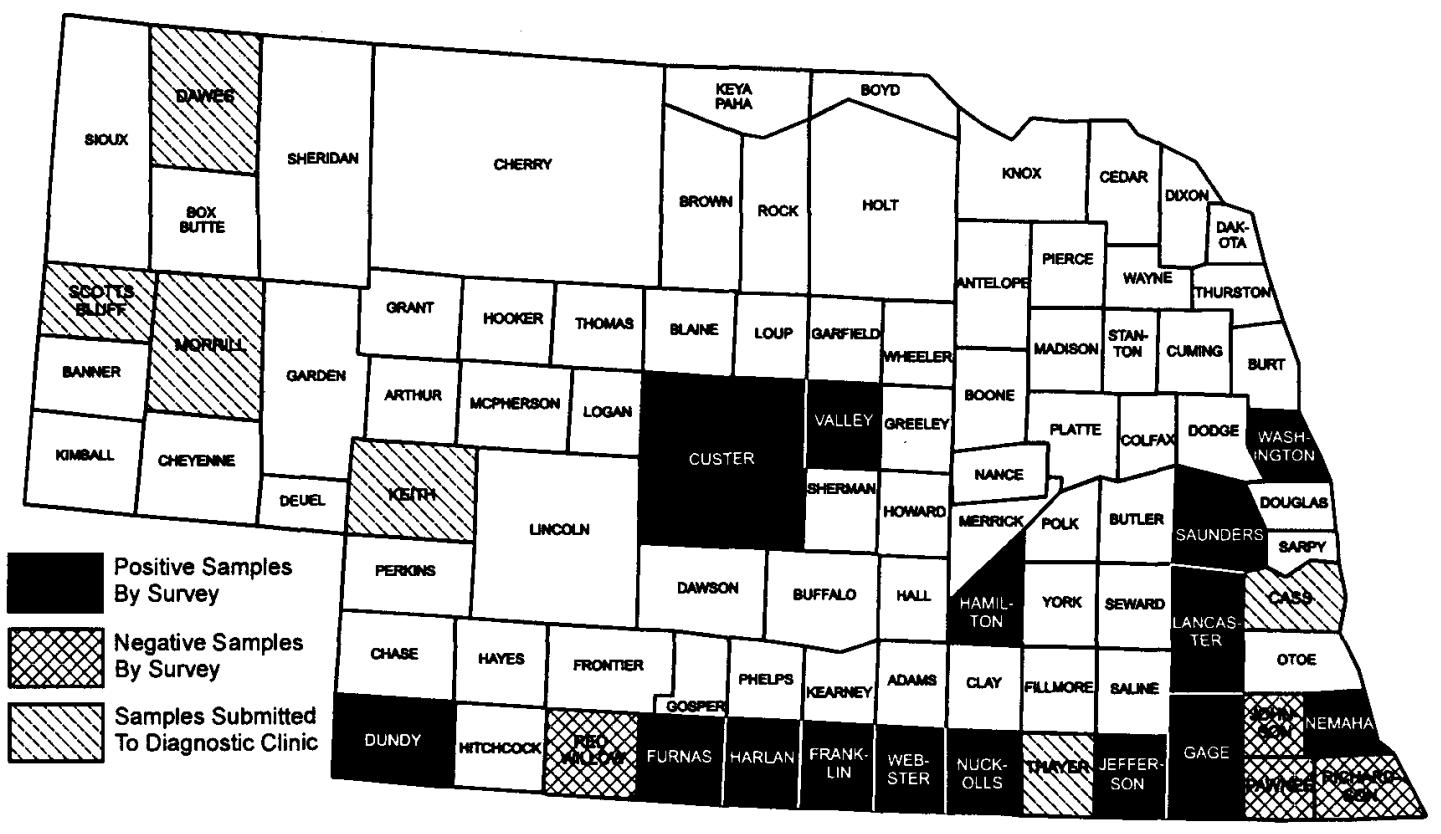

Fig. 3. Known distribution of B. occiduus in Nebraska.

fifth instars) B. occiduus were extracted from the 4 ' 609 ' buffalograss sod cores. This confirms the status of buffalograss as a reproductive host of this chinch bug. Twenty-one ( 1 brachypterous female, 20 first instars) and 2 (4th instars) chinch bugs were extracted from the Kentucky bluegrass and perennial ryegrass sod cores, respectively, indicating these turfgrasses may also serve as $B$. occiduus hosts. However, no chinch bugs survived on the bentgrass, tall fescue, or zoysiagrass sod cores. This suggests these turfgrass species may not be suitable hosts for $B$. occiduus. Other grass hosts from which $B$. occiduus has been collected include yellow bristlegrass, Seteria glanca (Weigel) Hubbard, and prairie sand reed grass, Calamovilfa longifolia (Hooker) Scribner (T. J. Henry and F.P.B., unpublished data).

Considerable progress has been made in identifying the arthropod complex associated with buffalograss. However, implementation of a comprehensive buffalograss-integrated pest management program has been hampered by limited knowledge of potential insect and mite pests. Information on the biology, distribution, and injury potential of $B$. acciduus obtained from this research will be used to develop effective, sustainable, and environmentally responsible management strategies for this potentially serious pest of buffalograss.

\section{Acknowledgments}

We gratefully acknowledge Z B Mayo and R. J. Wright for reviewing the manuscript; T. J. Henry for identification of this chinch bug; J. Kalisch for illustration of chinch bugs; and T. Weinhold, B. Irving, and B. Japp (University of Nebraska) for technical assistance. This research was supported in part by the University of Nebraska Agricultural Experiment Station Project 17-051, the United States Golf Association, and the Nebraska Turfgrass Foundation. This is paper 12491 of the journal series of the Agricultural Research Division, University of Nebraska-Lincoln.

\section{References Cited}

Barber, H. G. 1918. A new species of Leptoglossus: a new Blissus and varieties. Bull. Brooklyn Entomol. Soc. 13: 36

Baxendale, F. P., J. M. Johnson-Cicalese, and T. P. Riordan. 1994. Tridiscus sporoboli and Trionymus sp. (Homoptera: Pseudococcidae): potential new mealybug pests of buffalograss turf. J. Kans. Entomol. Soc. 67: 169-172.

Bird, R. D., and A. V. Mitchener. 1950. Insects of the season 1949 in Manitoba. Can. Insect Pest Rev. 28: 41.

Dingle, H. 1979. Adaptive variation in the evolution of insect migration, pp. 64-85. In R. L. Rabb and G. G. Kennedy [eds.], Movement of highly mobile insects: concepts and methodology in research. North Carolina State University, Raleigh.

Farstad, C. W., and Staff, A. 1951. Insects of the season in Alberta, 1950. Can. Insect Pest Rev, 29; 18.

Ferris, G. F. 1920. Insects of economic importance in the Cape Region of Lower California, Mexico. J. Econ. Entomol. 13: 463-467.

Horton, J. R., and A. F. Satterthwait. 1922. The chinch bug and its control. U.S. Dep. Agric. Farmers Bull. 1223.

Leonard, D. E. 1966. Biosystematics of the "Leucopterus Complex" of the genus Blissus (Heteroptera: Lygaeidae). Conn. Agric. Exp. Stn. Bull. 677: 1-47.

Mailloux, G., and H. T. Streu. 1981. Population biology of the hairy chinch bug (Blissus leucopterus hirtus, Montandon: Hemiptera: Lygaeidae). Ann. Soc. Entomol. Que. 26: 51-90.

Parker, J. R. 1920. The chinch bug in Montana. J. Econ. Entomol. 13: 318-322. 
Pozarnsky, T. 1983. Buffalograss: home on the range, but also a turf grass. Rangelands 5: 214-216.

Reinert, J. A., P. R. Heller, and R. L. Crocker. 1995. Chinch bugs, pp. 38-42. In R. L. Brandenburg and M. G. Villani [eds.], Handbook of turfgrass insect pests. Entomological Society of America, Lanham, MD.

Riordan, T. P., S. A. de Shazer, J. M. Johnson-Cicalese, and R. C. Shearman. 1993, An overview of breeding and development of buffalograss. Int.Turfgrass Soc. Res. J. 7: $816-822$

Skogley, C. R., and C. D. Sawyer. 1992. Field research, pp. 589-614. In D. V. Waddington, R. N. Carrow, and R. C. Shearman [eds.], Turfgrass. No. 32 in the series Agronomy. ASA, CSSA, SSA, Madison, WI.

Slater, J. A. 1964. A catalogue of the Lygaeidae of the world. University of Connecticut, Storrs.
Slater, J. A. 1979. The systematics, phylogeny, and zoogeography of the Blissinae of the world (Hemiptera, Lygaeidae). Bull. Am. Mus. Nat. Hist. 165.

Southwood, T.R.E. 1978. Ecological methods. Halsted, New York.

Tashiro, H. 1987. Turfgrass insects of the United States and Canada. Cornell University Press, Ithaca, NY.

Webster, F. M. 1909. The chinch bug (Blissus leucopterus Say). U.S. Dep. Agric. Bur. Entomol. Cir. 113: 1-27.

Wenger, L. E. 1943. Buffalo grass. Kans. Agric. Exp. Stn. Bull. 321.

Received for publication 22 January 1999; accepted 24 June 1999. 